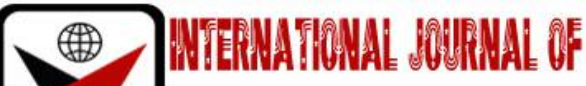

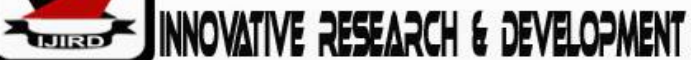

ISSN 2278 - 0211 (Online)

\section{A Matrix of Strategies in Teaching Biology: An Input to Pre-Service Teachers}

\begin{tabular}{c}
\hline Ronnie O. Daganasol \\
Student, Department of Biology, Visayas State University, Baybay City, Philippines \\
Damme Van C. Macasadog \\
Researcher, Department of Biological Sciences, Leyte Normal University, Tacloban City, Philippines \\
Christine Joy A. Pilande \\
Teacher, Department of Biological Sciences, Leyte Normal University, Tacloban City, Philippines \\
Maria Lourdes G. Tan \\
Research Coordinator, College of Education, Leyte Normal University, Tacloban City, Philippines
\end{tabular}

\begin{abstract}
:
A large percentage of pre-service teachers are facing problems during their practicum since they do not have sufficient knowledge about teaching strategies and when it should be integrated into instruction. This study is a descriptive research employing a survey method using a survey questionnaire and interview in the collection of data. It aims to identify the common and not commonly used strategies by in-service Biology teachers in teaching Biology in terms of content and skill. It is anchored on the K to 12 Basic Education Curriculum substantiated by Outcome-Based Teaching and Learning Theory. The participants were selected through random sampling including 72 in-service public Junior High School Biology teachers in which 29 were teaching Grade 7, 27 in Grade 8, 27 in Grade 9, and 25 in Grade 10. Data were tabulated using frequency count and were analyzed using percentage analysis. Results showed that lecturediscussion is the commonly used strategy in teaching the content yet considered to be the most ineffective strategy based on the interview, while cooperative learning is the commonly used strategy in teaching in terms of skills. Not commonly used strategies in teaching the content include jingle, music creation, poster-making, word puzzle, and think-pair-share while word puzzle for the skills. The result of the study pointed out the need for more training and seminars regarding the use of innovative science teaching strategies which will help improve students' performance in Biology both in content and skills.
\end{abstract}

Keywords: Biology education, teaching strategies, in-service teachers, pre-service teachers

\section{Introduction}

Teachers are traditionally known to impart knowledge solely, but in today's context, it is not enough for a teacher who is already in-service to teach in a vacuum, confirming on what is conventional. Instead, teachers now look for possible ways on how to deliver their instruction effectively by keeping students motivated and engaged. The teacher as implementer has to choose the right strategies to render effective teaching and instruction to learners (Pambid 2015; Boiser 2000) aside from the fact that there are numerous learning and teaching strategies freely available. Teaching strategies alongside the teacher's knowledge about the curriculum and mastery of the subject matter are one of the determinants in the effectiveness of the curriculum (Kamamia 2014; Duze 2012). It can be deduced that the fundamental importance of teaching strategies is to make teaching instruction efficient and effective by implementing a variety of teaching methods and techniques; hence, having a repertoire of a variety of teaching strategies will help students take more responsibility and enhance their learning as well as to improve the process of teaching for learning. However, large percentage of the pre-service teachers who are expected to be in-service teachers in the future are facing problems in integrating teaching strategies for their instruction during their practicum since they lack the exposure to these strategies (Mangila, 2018).

For an easy integration of strategies to instruction, this research undertaking specifically aimed to: (a) find out the commonly and not commonly used strategies used by selected in-service Public Junior High School Biology teachers in teaching Biology (Living Things and Their Environment) in terms of content and skills and (b) to develop a matrix that will serve as a guide in choosing the strategies in teaching Biology contents and skills.

\section{Theoretical Framework}

The study is anchored on the $\mathrm{K}$ to 12 Basic Education Curriculum, also known as Enhanced Basic Education Curriculum that offers a decongested 12-year program. As the current curriculum used in the Philippine educational system gives students sufficient time to master skills and absorb necessary competencies to provide teaching approaches that could improve the teaching and learning process. In line with this theory is the Outcomes-Based Teaching and 
Learning which focuses on student-centered approaches rather than teacher-centered approaches in the delivery of educational programs (Garrett, 2008; Llanes, 2010). As cited in the paper of Magtolis (2013) and Livingstone (2014), it has its roots from the idea of Biggs and Tang (2011) who further called OBTL as constructive alignment because students can construct meaning out of the relevant activities they are exposed. Moreover, Piaget's constructivism is affixed to the curriculum because of the integration of the spiral progression approach where current in-service teachers have a choice on what teaching strategies to use to come up with a meaningful learning experience (Bada, 2015).

Catering diverse intelligences of the students which enables a teacher to choose appropriate methods and strategies to use in instruction is the primary concern of Gardner's multiple intelligences theory. It emphasizes what the learner can bring inside the classroom by providing cues to what strategies the teacher can employ while considering individual characteristics (Bordei, 2016). According to Lewis (2012) as mentioned in the paper of Gorontalo (2018), allowing students to perform specific tasks together as divided into small groups develops critical thinking skills and cooperative learning because they are part of the discussion. Contemporary teaching can be best implemented through learning by design and project-based learning as it contends that building knowledge occurs best through making things that are tangible and sharable (Ralph 2015; Ackerman et al. 2009). It is supported by Wurdinger and Carlson (2010) who stated that students' learning must be facilitated by the instructor for them to apply their knowledge and conceptual understanding of real-world problems or authentic situations. This thought highlights experiential learning where teachers must employ a strategy to help bring about learning by trying to emphasize issues relevant to the learners and the context, they are in.

Indeed, upholding to these theories and approaches helped to assimilate the realization of the core learning area standard that develops scientific, technological and environmental literacy among learners as prescribed by the $\mathrm{K}$ to 12 Science curriculum. By integrating them across science topics and other disciplines with the aid of the spiral progression approach result to a meaningful understanding of concepts and direct application to real-life situations.

\subsection{Conceptual Framework}

The study is directed to answers the identified problems with the use of the schematic diagram shown below.

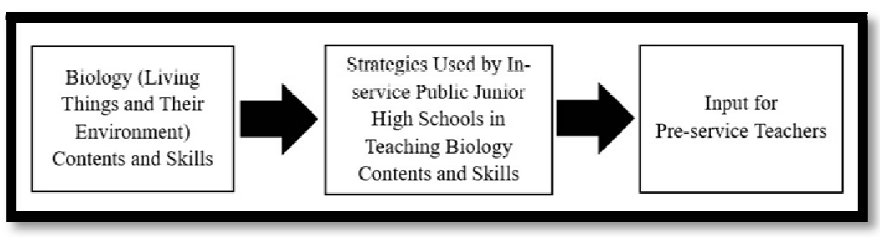

Figure 1: Conceptual Framework of the Study

The figure shows how the study looked into the teaching of Biology (Living Things and Their Environment) contents and skills in the field concerning to the contemporary methods and strategies used by in-service Public Junior High School to bring about the commonly used strategies and develop a matrix containing the possible strategies that can be used in choosing teaching strategies. Collectively, the findings and results will serve as an input to other in-service teachers and to pre-service teachers in becoming an effective teacher by equipping and immersing themselves into a variety of strategies and when to use them. The impact on them would be an additional input to the various educational-related individuals and authorities regarding what to retain, improve, and remove during instruction.

\subsection{Review of Related Literature}

Science, engineering, and technology has been widespread in every feature of modern life and used as an instrument to conquer humanity's most pressing challenges. The journey to seek an answer to a problem by exhibiting methods and principles in Science is to acquaint with the ever-flourishing technology advancements and to know and understand the challenges faced by the environment. These are the most critical components of the learning process in the 21st century Science teaching which the Committee on Conceptual Framework for New K to 12 Science Education Standards designed the framework comprising the broad set of expectations for students in Science. In the Philippines, this can be reflected in the $\mathrm{K}$ to 12 Science curriculum which envisions the development of scientifically, technologically, and environmentally literate and productive members of society who are critical problem solvers, responsible stewards of nature, innovative and creative citizens, informed decision makers, and effective communicators.

Teachers, as one of the determinants of the success of a curriculum, bombarded with vast strategies can use them in today's teaching instruction. It is crucial to remember that not every strategy can or should be applied in every teaching situation. Instructional strategies serve as tools in designing and implementing instruction; hence, these can be used synchronously provided that it serves its purpose which is to support and nurture student learning. Based from the report of Schroeder et al. (2002), the Center for Mathematics and Science Education Project of Texas in A\&M University presented descriptions of the identified effective research-based strategies in teaching $\mathrm{K}$ to 12 Science which includes enhanced context strategies, collaborative grouping strategies, questioning strategies, inquiry strategies, manipulation strategies, assessment strategies, instructional strategies, and enhanced material strategies.

Effective science teachers are those who recognize suitable methods for teaching specific concepts or skills in different situations that provide appropriate instruction and those who have a vast array of instructional strategies and methods available to produce successful learning. Pre-service teachers as future educators play a vital role in the component and integral part of the curriculum (Alsubaie 2016; Mavrogiorgos 2014; Avgitidis 2007;). It is claimed that 
many pre-service teachers have considered their pre-service teaching or practicum to be the most significant influence upon learning how to teach (Adoniou 2013; Hastings 2010). However, it was observed that the pre-service teachers do not have sufficient knowledge about teaching strategies, methods, and techniques and that they cannot even distinguish between these concepts (Pambid 2015; Gunes et al. 2011).

In today's setting, if the teacher intends to create more interactive learning environments, he or she has to integrate technology and use innovative strategies applicable into the learning experience because students are more likely interested and abreast. The world today is changing and advancing so teachers especially the pre-service teachers who are to be in-service teachers in the future need to be flexible, innovative and technology savvy. Thus, this calls for the identification of the strategies used by the present in-service teachers and the development of a repertoire of strategies for the immersion of the pre-service teachers to this variety of strategies. So as to create meaningful learning in the process of teaching and learning that requires contextualization by bridging the students' real-life experiences into the content and deliverance.

\section{Methodology}

\subsection{Research Design}

The study utilized a descriptive research design employing a survey method in the collection of data where the respondents answer questions administered through survey questionnaires where quantifiable information was used for statistical inference. The data gathered were validated through conducting interviews to further elaborate their answers and to strengthen the reliability of the results.

\subsection{Research Locale}

The information presented in this study is geographically based in the Tacloban City Division where the participants are currently affiliated. Tacloban City as the regional center of the region of Eastern Visayas and despite being autonomous from the province of Leyte, still many educationally- motivated individuals in nearby municipalities and provinces seek to enroll because of the various public and private institutions that provide an excellent training ground for productive individuals in the future.

\subsection{Sampling Procedure}

The sampling technique utilized was random sampling wherein the researchers selected the respondents randomly for the pilot testing and during the actual data gathering by getting the list of all schools under the Division of Tacloban City and each school provided the number of teachers teaching Biology. Out of the 88 teachers, 13 teachers were chosen as the participants for pilot testing to achieve feasibility and 72 teachers for the actual data gathering with $95 \%$ confidence level and 5\% margin of error for the results to establish reliability.

\subsection{Data Instrument and Collection}

Researchers have sought permission to each of the chosen schools where the study was conducted. The use of a survey questionnaire as an instrument was then distributed to the research respondents where they have to provide their demographic profile and placed a checkmark before the name of the strategy or strategies, they are utilizing in teaching Biology contents and skills. A follow-up interview consisted by eight open-ended questions was conducted to support their answers on the survey questionnaire and holistically develop the matrix for the possible instructional strategies that can be used in teaching Biology (Living Things and Their Environment). The gathered data were tabulated, analyzed and interpreted by using frequency count and percentage analysis as statistical tools. The different strategies used by the respondents in teaching the contents and skills in Biology in each grade level were tallied to derive the frequency of each strategy as well as to determine the value percentage. These enable to identify the common and not commonly used strategies in teaching Biology contents and skills and the matrix to be developed.

\subsection{Data Analysis}

The gathered data during the pilot testing and actual data collection were coded and tallied for commonalities. Frequency count and percentage analysis were used to analyze the data provided by the respondents to give accurate interpretations and conclusions of the results gathered during the survey conducted. In the form of a table, all the strategies used in teaching Biology contents and skills were summarized to develop the matrix.

\section{Results and Discussion}

This chapter presented the results of the research study drawn out from the answers of the respondents in the survey questionnaires and interviews with the corresponding interpretation and analysis. They are presented in a manner that they sequentially answer the research questions. 


\begin{tabular}{|c|c|c|c|c|c|c|c|c|c|c|c|c|c|c|c|c|c|}
\hline \multicolumn{18}{|c|}{ A. Age and Sex } \\
\hline \multirow{3}{*}{ Age } & \multicolumn{15}{|c|}{ Sex } & \multirow{3}{*}{ Total } & \multirow{3}{*}{ Percentage } \\
\hline & \multicolumn{4}{|c|}{ Male } & \multirow{2}{*}{$\mathbf{T}$} & \multicolumn{4}{|c|}{ Female } & \multirow{2}{*}{$\mathbf{T}$} & \multicolumn{4}{|c|}{ DNS } & \multirow{2}{*}{$\mathbf{T}$} & & \\
\hline & G7 & G8 & G9 & G10 & & G7 & G8 & G9 & G10 & & G7 & G8 & G9 & G10 & & & \\
\hline $21-30$ & 1 & 1 & 0 & 3 & 5 & 3 & 9 & 7 & 4 & 23 & - & - & - & - & 0 & 28 & $30 \%$ \\
\hline $31-40$ & 0 & 0 & 1 & 0 & 1 & 2 & 4 & 4 & 7 & 17 & - & - & - & - & 0 & 18 & $19 \%$ \\
\hline $41-50$ & 0 & 2 & 1 & 0 & 3 & 1 & 1 & 3 & 2 & 7 & - & - & - & - & 0 & 10 & $11 \%$ \\
\hline $51-60$ & 0 & 0 & 1 & 0 & 1 & 0 & 4 & 1 & 1 & 6 & - & - & - & - & 0 & 7 & $8 \%$ \\
\hline DNS & - & - & - & - & - & - & - & - & - & - & 7 & 6 & 9 & 8 & 30 & 30 & $32 \%$ \\
\hline \multicolumn{5}{|c|}{ Total } & 10 & & & & & 53 & & & & & 30 & 93 & $100 \%$ \\
\hline \multicolumn{5}{|c|}{ Percentage } & $11 \%$ & & & & & $57 \%$ & & & & & $32 \%$ & $100 \%$ & \\
\hline \multicolumn{8}{|c|}{ B. Specialization or Major Field } & \multicolumn{10}{|c|}{ C. Highest Educational Degree } \\
\hline \multirow{2}{*}{\multicolumn{2}{|c|}{ Specialization }} & \multicolumn{4}{|c|}{$f$} & \multirow{2}{*}{$\mathbf{T}$} & \multirow{2}{*}{$\%$} & \multirow{2}{*}{\multicolumn{4}{|c|}{ Educational Degree }} & \multicolumn{4}{|c|}{$f$} & \multirow{2}{*}{$\mathbf{T}$} & \multirow{2}{*}{$\%$} \\
\hline & & G7 & G8 & G9 & G10 & & & & & & & G7 & G8 & G9 & G10 & & \\
\hline \multicolumn{2}{|c|}{ Biological Sciences } & 15 & 16 & 8 & 6 & 45 & 42 & \multicolumn{4}{|c|}{ Bachelor's Degree } & 12 & 12 & 16 & 12 & 52 & 48 \\
\hline \multicolumn{2}{|c|}{ Physical Sciences } & 3 & 1 & 6 & 13 & 23 & 21 & Mast & er's De & gree & & 10 & 8 & 2 & 7 & 27 & 25 \\
\hline General S & nces & 8 & 7 & 5 & 5 & 25 & 23 & Doct & rate $D$ & egree & & 1 & 1 & 2 & 0 & 4 & 4 \\
\hline Others & & 2 & 1 & 3 & 0 & 6 & 6 & Supp & lement & al Degr & & 1 & 0 & 0 & 0 & 1 & 1 \\
\hline DNS & & 1 & 2 & 5 & 1 & 9 & 8 & DNS & & & & 5 & 6 & 7 & 6 & 24 & 22 \\
\hline & & $\overline{\text { OTA }}$ & & & & 108 & 100 & & & & TO & $\overline{A L}$ & & & & 108 & 100 \\
\hline D. Length & Time & Spe & $\operatorname{tin} 1$ & eacl & ng Bio & $\log y$ & & E. Ne & tur & f Appo & ointm & & & & & & \\
\hline No of & & & & $f$ & & $T$ & $\%$ & Natu & re of $A$ & pnoint & ment & & & $f$ & & $T$ & $\%$ \\
\hline & & G7 & G8 & G9 & G10 & & & & & & & G7 & G8 & G9 & G10 & & \\
\hline 1 to 5 yea & & 12 & 12 & 16 & 10 & 50 & 46 & Teac & eer 1 & & & 4 & 5 & 7 & 7 & 23 & 21 \\
\hline 6 to 10 ye & & 7 & 3 & 3 & 7 & 20 & 19 & Teac & er 2 & & & 3 & 2 & 1 & 1 & 7 & 6 \\
\hline 11 to $15 \mathrm{y}$ & & 2 & 4 & 3 & 3 & 12 & 11 & Teac & ner 3 & & & 12 & 9 & 8 & 9 & 38 & 35 \\
\hline Others & & 6 & 5 & 1 & 2 & 14 & 13 & Othe & & & & 6 & 5 & 2 & 1 & 14 & 13 \\
\hline DNS & & 2 & 3 & 4 & 3 & 12 & 11 & DNS & & & & 4 & 6 & 9 & 7 & 26 & 24 \\
\hline & & $\overline{\text { OTA }}$ & & & & 108 & 100 & & & & TO & $\overline{A L}$ & & & & 108 & 100 \\
\hline
\end{tabular}

Table 1: Profile of the Respondents of the Study

The respondents of the study included seventy-two (72) teachers who are composed mainly of females belonging to the age group between 21-30 years old with Biological Sciences as their major field of specialization and Bachelor's degree for their highest educational degree attained. Most of the teachers have taught Biology in the span of 1 to 5 years due to the ever-changing system of giving loads and preparation to the teachers. However, in terms of their nature of appointment of their service, mostly are Teacher 3 which implies that they are engaged in continued professional development. It is important to take note that the total number respondents reflected in Table 1 may exceed the total number of respondents of the study because some of the teachers teach Biology in other grade levels.

\begin{tabular}{|c|c|c|c|c|c|c|c|}
\hline$r$ & Strategy & $f$ & 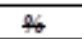 & $r$ & Strategy & $f$ & 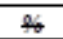 \\
\hline 1 & Lecture-Discussion & 481 & 28.13 & \multirow{2}{*}{18} & Bogrdwork & 13 & 0.79 \\
\hline 2 & Multimedis Instruction & 421 & 25.69 & & Pid: and Match & 13 & 0.79 \\
\hline 3 & Brainstorming & 98 & 5.98 & 19 & Direct hstruction & 12 & 0.73 \\
\hline 4 & Cooperative Learning & 77 & 4.70 & 20 & Situgtiongl Anghs is & 11 & 0.67 \\
\hline 5 & Role Plgying & 48 & 2.93 & \multirow{2}{*}{21} & $4 \mathrm{Pias} 1$ Word & 9 & 0.55 \\
\hline 8 & Picture Anghs is & 43 & 2.82 & & Video Mlaking & 9 & 0.55 \\
\hline 7 & Cues and Questioning & 41 & 2.50 & 22 & Simulation & 8 & 0.49 \\
\hline 8 & In-School Field Experience & 38 & 2.32 & \multirow{3}{*}{23} & GalleryWak & 7 & 0.43 \\
\hline 9 & Research Review & 37 & 2.26 & & $\mathrm{~K}-\mathrm{W}-\mathrm{H}-\mathrm{L}$ & 7 & 0.43 \\
\hline \multirow{2}{*}{10} & Concept Mapping & 32 & 1.95 & & Poem Mlaking & 7 & 0.43 \\
\hline & Reporting & 32 & 1.95 & \multirow{3}{*}{24} & Cheodlist & 5 & 0.31 \\
\hline 11 & Laboratory Activity & 31 & 1.89 & & Memory Game & 5 & 0.31 \\
\hline 12 & Model Making & 30 & 1.83 & & Trivia Question & 5 & 0.31 \\
\hline 13 & Jigs gN & 22 & 1.34 & 25 & Realias & 4 & 0.24 \\
\hline 14 & Show and Tell & 21 & 1.28 & \multirow{5}{*}{28} & Jingle & 1 & 0.08 \\
\hline 15 & Graphic Organizer & 20 & 1.22 & & MusicCregtion & 1 & 0.08 \\
\hline 18 & Fim Stowing & 19 & 1.18 & & Poster Making & 1 & 0.08 \\
\hline \multirow{3}{*}{17} & Consequence Mapping & 16 & 0.98 & & Think-Pair-Share & 1 & 0.08 \\
\hline & P.O.E. & 18 & 0.98 & & Word Puzzle & 1 & 0.08 \\
\hline & Venn Diagram & 18 & 0.98 & \multirow{2}{*}{39} & \multirow{2}{*}{ TOT AL } & \multirow{2}{*}{1519} & \multirow{2}{*}{100} \\
\hline Con & tinue to the next column & & & & & & \\
\hline
\end{tabular}

Table 2: Strategies Used Across All Grade Levels in Teaching Biology in Terms of the Content

The results revealed that 39 strategies were utilized by the selected Biology teachers across all grade levels in teaching Biology in terms of the content. Relative to this, lecture-discussion was the commonly used strategy while jingle, music creation, poster making, think-pair-share, and word puzzle were the strategies which are not commonly used. Lecture-discussion is the best teaching method that can be applied in many circumstances and for many students especially for communicating conceptual knowledge (Charlton, 2006) like in teaching the contents in Biology. In 2014, the Center for Instructional Development and Distance Education argued that despite its disadvantages such as providing students with individual feedback, difficult to adapt to learning differences and failure to promote independent learning can be addressed by incorporating into the lecture with other teaching strategies like questioning and problem-solving activities will surely support active learning. 


\begin{tabular}{|c|c|c|c|c|c|c|c|}
\hline$r$ & Strategy & $f$ & $\%$ & $r$ & Strategy & $f$ & $\%$ \\
\hline 1 & Cooperative Learning & 354 & 12.26 & 26 & Show and Tell & 16 & 0.55 \\
\hline 2 & Multimedia Instruction & 314 & 10.88 & \multirow{3}{*}{27} & Targeted Feedback & 15 & 0.52 \\
\hline 3 & Laboratory Activity & 305 & 10.56 & & Tracking One's Meal & 15 & 0.52 \\
\hline 4 & Brainstorming & 217 & 7.52 & & Trivia Question & 15 & 0.52 \\
\hline 5 & Picture Analysis & 166 & 5.75 & \multirow{3}{*}{28} & 4 Pics 1 Word & 14 & 0.48 \\
\hline 6 & Boardwork & 123 & 4.26 & & Music Creation & 14 & 0.48 \\
\hline 7 & Role Playing & 86 & 2.98 & & Planning A Healthy Diet & 14 & 0.48 \\
\hline 8 & P.O.E. & 84 & 2.91 & 29 & Name Game & 13 & 0.45 \\
\hline 9 & Model Making & 77 & 2.67 & \multirow{4}{*}{30} & Debate & 12 & 0.42 \\
\hline 10 & Comic Strip Making & 72 & 2.49 & & Gallery Walk & 12 & 0.42 \\
\hline \multirow{2}{*}{11} & Graphic Organizer & 68 & 2.36 & & Modelling & 12 & 0.42 \\
\hline & In-School Field Experience & 68 & 2.36 & & Peer Teaching & 12 & 0.42 \\
\hline 12 & Venn Diagram & 64 & 2.22 & \multirow{3}{*}{31} & 3-Day Menu & 11 & 0.38 \\
\hline 13 & Lecture-Discussion & 59 & 2.04 & & Making Illustrations & 11 & 0.38 \\
\hline 14 & Simulation & 55 & 1.91 & & Word Wall & 11 & 0.38 \\
\hline 15 & Lecture-Demonstration & 50 & 1.73 & \multirow{2}{*}{32} & Film Showing & 10 & 0.35 \\
\hline 16 & Concept Mapping & 49 & 1.70 & & Instructional Analysis & 10 & 0.35 \\
\hline 17 & Situational Analysis & 46 & 1.59 & 33 & Memory Game & 9 & 0.31 \\
\hline 18 & Direct Instruction & 39 & 1.35 & \multirow{2}{*}{34} & Journal Making & 8 & 0.28 \\
\hline \multirow{2}{*}{19} & Consequence Mapping & 38 & 1.32 & & Think-Pair-Share & 8 & 0.28 \\
\hline & Reporting & 38 & 1.32 & 35 & Integration with Other Conten & 7 & 0.24 \\
\hline 20 & Research Review & 27 & 0.94 & 36 & Survey Activity & 6 & 0.21 \\
\hline 21 & Collaborative Learning & 26 & 0.90 & \multirow{3}{*}{37} & Culminating Activity & 5 & 0.17 \\
\hline 21 & Picture Puzzle & 26 & 0.90 & & Reaction Papers & 5 & 0.17 \\
\hline 22 & Classifying Organisms & 24 & 0.83 & & Realias & 5 & 0.17 \\
\hline 23 & Reciprocal Teaching & 22 & 0.76 & \multirow{2}{*}{38} & Focus Group Discussion & 4 & 0.14 \\
\hline 24 & Advertisement Making & 19 & 0.66 & & Video Making & 4 & 0.14 \\
\hline \multirow{2}{*}{25} & Cues and Questionning & 18 & 0.62 & \multirow{2}{*}{39} & Poem Making & 3 & 0.10 \\
\hline & Story Making & 18 & 0.62 & & R.E.P.R. & 3 & 0.10 \\
\hline \multirow{3}{*}{26} & Jigsaw & 16 & 0.55 & 40 & Poster Making & 2 & 0.07 \\
\hline & Playing A Board Game & 16 & 0.55 & 41 & Word Puzzle & 1 & 0.03 \\
\hline & Project-Based Task & 16 & 0.55 & \multirow{2}{*}{63} & \multirow{2}{*}{ TOTAL } & \multirow{2}{*}{2600} & \multirow{2}{*}{100} \\
\hline & e next cc & & & & & & \\
\hline
\end{tabular}

\section{Table 3: Strategies Used Across All Grade Levels In Teaching Biology In Terms Of The Skills}

On the other hand, the commonly used strategy by selected Biology teachers in teaching Biology in terms of the skills was cooperative learning and word puzzle as the not commonly used strategy. Cooperative learning is employed by teachers to increase student understanding of content, to build particular transferable skills, or some combination of the two from small group work to capitalize on the impacts of peer-to-peer interaction and discussion (Brame and Biel 2015; Johnson et al. 2008). Promoting students in working together maximize their own and each other's learning is the primary instructional use of small groups. Johnson and Johnson (2015) stressed that cooperative learning has characterized by positive interdependence, where students perceive that better performance by individuals produces better performance by the entire group. They also added that it is one of the most effective teaching approaches to be used to analyze the results of the activities performed.

\begin{tabular}{|c|c|c|c|c|c|c|c|}
\hline & Strategy & $f$ & $\%$ & $r$ & Strategy & $f$ & $\%$ \\
\hline 1 & Multimedia Instruction & 735 & 16.60 & 31 & Story Making & 18 & 0.41 \\
\hline 2 & Lecture-Discussion & 520 & 11.74 & \multirow{2}{*}{3} & Playing A Board Game & 16 & 0.36 \\
\hline 3 & Cooperative Learning & 431 & 9.73 & & Project-Based Task & 16 & 0.36 \\
\hline 4 & Laboratory Activity & 336 & 7.59 & \multirow{3}{*}{33} & Music Creation & 15 & 0.34 \\
\hline 5 & Brainstorming & 315 & 7.11 & & Targeted Feedback & 15 & 0.34 \\
\hline 6 & Picture Analysis & 209 & 4.72 & & \begin{tabular}{|l|} 
Tracking One's Meal \\
\end{tabular} & 15 & 0.34 \\
\hline 7 & Boardwork & 136 & 3.07 & \multirow{2}{*}{34} & Memory Game & 14 & 0.32 \\
\hline 8 & Role Playing & 134 & 3.03 & & \begin{tabular}{|l|} 
Planning A Healthy Diet \\
\end{tabular} & 14 & 0.32 \\
\hline 9 & Model Making & 107 & 2.42 & \multirow{3}{*}{35} & Name Game & 13 & 0.29 \\
\hline 10 & In-School Field Experience & 106 & 2.39 & & Pick and Match & 13 & 0.29 \\
\hline 11 & P.O.E. & 100 & 2.26 & & Video Making & 13 & 0.29 \\
\hline 12 & Graphic Organizer & 88 & 1.99 & \multirow{3}{*}{36} & Debate & 12 & 0.27 \\
\hline 13 & Concept Mapping & 81 & 1.83 & & Modelling & 12 & 0.27 \\
\hline 14 & Venn Diagram & 80 & 1.81 & & Peer Teaching & 12 & 0.27 \\
\hline 15 & Comic Strip Making & 72 & 1.63 & \multirow{3}{*}{37} & 3-Day Menu & 11 & 0.25 \\
\hline 16 & Reporting & 70 & 1.58 & & Making Illustrations & 11 & 0.25 \\
\hline 17 & Research Review & 64 & 1.45 & & Word Wall & 11 & 0.25 \\
\hline 18 & Simulation & 63 & 1.42 & \multirow{2}{*}{38} & Instructional Analysis & 10 & 0.23 \\
\hline 19 & Consequence Mapping & 54 & 1.22 & & Poem Making & 10 & 0.23 \\
\hline 20 & Direct Instruction & 51 & 1.15 & \multirow{2}{*}{39} & Realias & 9 & 0.20 \\
\hline 21 & Lecture-Demonstration & 50 & 1.13 & & Think-Pair-Share & 9 & 0.20 \\
\hline 22 & Jigsaw & 38 & 0.86 & 40 & Journal Making & 8 & 0.18 \\
\hline 23 & Show and Tell & 37 & 0.84 & \multirow{2}{*}{41} & Integration with Other Content A & 7 & 0.16 \\
\hline 24 & Film Showing & 29 & 0.65 & & K-W-H-L & 7 & 0.16 \\
\hline 25 & Collaborative Learning & 26 & 0.59 & 42 & Survey Activity & 6 & 0.14 \\
\hline 26 & Picture Puzzle & 26 & 0.59 & \multirow{3}{*}{43} & Checklist & 5 & 0.11 \\
\hline 20 & Classifying Organisms & 24 & 0.54 & & Culminating Activity & 5 & 0.11 \\
\hline 27 & 4 Pics 1 Word & 23 & 0.52 & & Reaction Papers & 5 & 0.11 \\
\hline 28 & Reciprocal Teaching & 22 & 0.50 & 44 & Focus Group Discussion & 4 & 0.09 \\
\hline 29 & Trivia Question & 20 & 0.45 & \multirow{2}{*}{45} & Poster Making & 3 & 0.07 \\
\hline \multirow{2}{*}{30} & Advertisement Making & 19 & 0.43 & & R.E.P.R. & 3 & 0.07 \\
\hline & Gallery Walk & 19 & 0.43 & 46 & Word Puzzle & 2 & 0.05 \\
\hline 31 & Cues and Questionning & 18 & 0.41 & 47 & Jingle & 1 & 0.02 \\
\hline \multicolumn{2}{|r|}{ Continue to the next column. } & & & 66 & TOTAL & 4103 & 100 \\
\hline
\end{tabular}

Table 4: Summary of All Teaching Strategies Used by Selected in-Service Public Junior High School Biology Teachers in Teaching Biology Content and Skills across All Grade Levels 
Moreover, out of 66 teaching strategies used by in-service Public Junior High School Biology teachers across all grade levels in teaching both the contents and skills in Biology, multimedia instruction is the commonly used strategy while jingle is the not widely used strategy.

The advantages such timeliness and effectiveness are one of the reasons why multimedia instruction is the most commonly used strategy among others because it altered the landscape in the educational arena by providing the students an opportunity to manage cognitive load which increases motivation (Mayer, 2014) and retention (Conrad and Bliemel, 2016) by developing inquisitiveness makes learning experiences purposeful (Ketsman 2014; Allen 2003). It also allows learners to be creative in a way that it will enable them to become active producers of knowledge by reducing the need for memorization through changing "how" by "why" in the classrooms according to Neary and Winn (2009). As revealed during the interview, excerpts are in the text below:

\section{INTVW, Exc. 1}

Teacher 11: $\quad$ Multimedia for me is the commonly used strategy especially that the students, the millennials nowadays are much more on multimedia rather than visual aids like

\section{Figure 1}

INTVW, Exc. 2

Teacher 10: The most effective teaching strategy is the multimedia presentation by downloading different kinds of video presentation which are related to my topic. It was indeed effective, most effective because students are learning a lot of things rather than chalk talk, like I talk while writing something on the

\section{Figure 2}

Despite being a commonly used strategy, problems still confront teachers upon its implementation particularly in the absence of electricity and unforeseen technicalities. However, teachers are said to be problem-solvers, so they provided interventions as cited by the teacher- respondents during the interview.

\section{INTVW, Exc. 3}

Teacher 4: $\quad$ As for the technical glitches, I made sure to set up my multimedia equipment ahead of time so as to avoid delay and wastage of time, especially if the laboratory activities and learner's materials are unavailable.

\section{Figure 3}

\section{INTVW, Exc. 4}

Teacher 10: If there are problems, I encountered in the multimedia, I actually give my PowerPoint presentation through an application for the students to have a copy.

\section{Figure 4}

The result indicated that lecture-discussion was the second common strategy and it is not surprising since its widespread use is well documented (Goffe and Kauper 2014; Smith and Valentine, 2012). According to Carnegie Mellon University (2019), it is an excellent strategy for enhancing student motivation, fostering intellectual agility, and provides avenues for exploration and discovery. However, numerous studies have demonstrated that traditional lectures relying on passive learning is not as effective as active, student-centered learning strategies (Lom 2012; Tanner 2009). It noted that lecturediscussion was pointed out by the respondents as least effective during the interview. The responses of the teachers attest this point of view written in the following text.

\begin{tabular}{ll|}
$\begin{array}{l}\text { INTVW, Exc. } 5 \\
\text { Teacher 5: }\end{array}$ & $\begin{array}{l}\text { The least effective strategy is the lecture-discussion because some of the students } \\
\text { are not listening, some were talking to their seatmates and some were not able to } \\
\text { understand what the teacher was talking about. }\end{array}$ \\
\end{tabular}

Figure 5

$\begin{aligned} & \text { INTVW, Exc. } 6 \\ & \text { Teacher 11: }\end{aligned}$
$\begin{aligned} & \text { Spoon feeding the students is not the trend any more for students tend to be bored } \\ & \text { most of the time. If teacher does the talking and the ideas and information are being } \\ & \text { spoon-fed by the teacher. It should be then the students, student-centered activities } \\ & \text { should be catered wherein the teacher will just serve as the facilitator in class. }\end{aligned}$

Figure 6 
However, considering this critical claim of the respondents is the answer to why there are contrasting results between the result of the survey and their responses in the interview as stipulated in the statement below

INTVW, Exc. 7

Teacher 13:

... teachers can use it anytime as long as you have the mastery of the lesson. As you can notice, teachers nowadays are not only tasked to teach, we also accomplish reports if you are aware of that. We are told to do so many things and we even play roles that are beyond the teaching profession. Sometimes it's painful to think that we cannot prepare that much for our lessons due to these additional roles we play in the school premises. So, when these situations occur, lecturediscussion would be a good alternative to use.

Figure 7

This claim implies that teachers resorted to using lecture- discussion despite its ineffectiveness considering it as suitable in all situations or an answer to any school's urges with their intention of not wasting time or establishing gaps between their lessons. It may be an excuse but the mere fact, it happens in the real scenario. Even the Guyana Ministry of Education (2017) also perceived the same claim that the traditional lecture method of teaching is the only way to be applied in all circumstances.

Upon gathering the necessary data, development of matrix completed the process which comprises all the strategies used by every grade level in-service Public Junior High School Biology teacher in the Division of Tacloban City in teaching Biology contents and skills. As the expected outcome of the study, it primarily intends to provide an input to pre-service teachers in practicing the field of teaching. As shown in the succeeding tables is the developed matrix of the study.

GRADE 7

Summary of All Strategies Used in Terms of the Content and Skill

\begin{tabular}{|c|c|c|c|c|}
\hline Content & Leaming Competency/ies & Strategies & Acitivitylies & Strategies \\
\hline \multicolumn{5}{|l|}{ 1. Parts and Functions } \\
\hline \multirow{15}{*}{ 1. Mcroscopy } & \multirow{7}{*}{$\begin{array}{l}\text { 1. idenoffy pars of the } \\
\text { microscope and their } \\
\text { functions; }\end{array}$} & Showand Tell & \multirow{6}{*}{$\begin{array}{l}\text { Acjivity 1. Howto Use the } \\
\text { Light Mcoscope }\end{array}$} & Laboratory Activity \\
\hline & & Simulation & & Cooperative Leaming \\
\hline & & Drect Instruction & & Film Shoving \\
\hline & & Lectue-Discussion & & Realias \\
\hline & & Word Puzzle & & Collaborative Activty \\
\hline & & \begin{tabular}{|l|} 
Lectue-Discussion \\
\end{tabular} & & Simulation \\
\hline & & Boardwork & \multirow{7}{*}{$\begin{array}{l}\text { Activty } 1 \text {. What makes up } \\
\text { an organism? }\end{array}$} & Picture Analysis \\
\hline & \multirow{8}{*}{$\begin{array}{l}\text { 2. focus specimens using } \\
\text { the compound microscope; }\end{array}$} & Laboratory Acjiviy & & Cooperative Leaming \\
\hline & & Malimedia Instruction & & Laboratory Activity \\
\hline & & Simulation & & Realias \\
\hline & & Direct Instruction & & 4 Pics 1 Word \\
\hline & & Lectue-Demonstration & & Collaborafive Leaming \\
\hline & & Lectue-Discussion & & Picture Analysis \\
\hline & & Mlimedia Instruction & \multirow{7}{*}{$\begin{array}{l}\text { Activty 2. Le vels of } \\
\text { organization in an org anism }\end{array}$} & Gaohic Organizer \\
\hline & & Simulation & & Brainstorming \\
\hline \multirow{8}{*}{$\begin{array}{l}\text { 2. Levels of Biological } \\
\text { Organization }\end{array}$} & \multirow{8}{*}{$\begin{array}{l}\text { 3. describe the different } \\
\text { levels of biological } \\
\text { organization from cell to } \\
\text { biosphere; }\end{array}$} & Graphic Organizer & & Laboratory Activity \\
\hline & & Lectue-Discussion & & Reporing \\
\hline & & Brainstorming & & Brainstorming \\
\hline & & Reporing & & Collaborafve Leaming \\
\hline & & Mlimedia Instruction & & Gaohic Organizer \\
\hline & & Jingle & \multirow{6}{*}{$\begin{array}{l}\text { Activty 1. Comparing plant } \\
\text { and animal cells }\end{array}$} & Venn Diagram \\
\hline & & Think-Pair-Share & & Model Making \\
\hline & & Word Puzzle & & Cooperative Leaming \\
\hline \multirow{15}{*}{$\begin{array}{l}\text { 3. Animal and Plant } \\
\text { Cells }\end{array}$} & \multirow{8}{*}{$\begin{array}{l}\text { 4. differentate plant and } \\
\text { animal cells according to } \\
\text { presence or absence of } \\
\text { certain org anelles; }\end{array}$} & Venn Diagram & & Laboratory Activity \\
\hline & & Meking Models & & Collaborafive Leaming \\
\hline & & Lectue-Discussion & & Boadvork \\
\hline & & Direct instruction & \multirow{5}{*}{$\begin{array}{l}\text { Acrivty } 2 \text {. Invesigating } \\
\text { plant cells }\end{array}$} & Laboratory Activity \\
\hline & & Mulimedial Instruction & & Mutimedia Instuccion \\
\hline & & Showand Tell & & Focus Gouo Discussion \\
\hline & & Brainstorming & & Gallery Walk \\
\hline & & Checklist & & Lecture-Discussion \\
\hline & \multirow{7}{*}{$\begin{array}{l}\text { 5. explain vhy the cell is } \\
\text { considered the basic } \\
\text { structural and functional unit } \\
\text { of all org anisms; }\end{array}$} & Milimedia Instruction & \multirow{5}{*}{$\begin{array}{l}\text { Activity } 1 \text {. Are the se also } \\
\text { plants? }\end{array}$} & n-School Field Trios \\
\hline & & Lectue-Discussion & & Brainstorming \\
\hline & & Brainstorming & & Laboratory Activity \\
\hline & & Laboratory Activity & & P.O.E. \\
\hline & & Reseach Revew & & Collaborabive Activity \\
\hline & & Reporing & \multirow{6}{*}{$\begin{array}{l}\text { Activity 2. What other living } \\
\text { things ae found in the } \\
\text { school grounds? }\end{array}$} & n-School Field Trips \\
\hline & & Collaborative Leaming & & Cooperative Leaming \\
\hline \multirow{9}{*}{$\begin{array}{l}\text { 4. Fungi, Protsss, and } \\
\text { Bactena }\end{array}$} & \multirow{9}{*}{$\begin{array}{l}\text { 6. idenofy be nefcial and } \\
\text { harnful microorg anisms; }\end{array}$} & Lectue-Discussion & & Mutimedia Instuction \\
\hline & & Cooperabive Leaming & & Laboratory Activity \\
\hline & & In-School Field Experience & & Collaboraive Leaming \\
\hline & & Realias & & Realias \\
\hline & & Mlimedia Instruction & \multirow{5}{*}{$\begin{array}{l}\text { Activity } 3 \text {. What do these } \\
\text { living things look like under } \\
\text { the microscope? }\end{array}$} & Laboratory Acfivity \\
\hline & & Collaborative Leaming & & Mutimedia Instuction \\
\hline & & Brainstorming & & Picture Analysis \\
\hline & & \begin{tabular}{|l|} 
Lectue-Demonstration \\
\end{tabular} & & Model Making \\
\hline & & & & Boadwork \\
\hline
\end{tabular}

Table 5 
GRADE 7

Summary of All Strategies Used $\boldsymbol{h}$ Terms of the Content and Skill

\begin{tabular}{|c|c|c|c|c|}
\hline Conternt & I Learning Competency/ies & Strategies & Acitivity/ies & Strategies \\
\hline \multicolumn{5}{|c|}{ 2. Heredity: Inheritance and Variation } \\
\hline \multirow{14}{*}{$\begin{array}{l}\text { 1. Asexual eproduction } \\
\text { 2. Sexual eproduction }\end{array}$} & \multirow{8}{*}{$\begin{array}{l}\text { 7. differentate ase xual from } \\
\text { sexual reproduction in terms } \\
\text { of. } \\
\text { 7. } 1 \text { number of individuals } \\
\text { nvolved; } \\
\text { 7. } 2 \text { similarties of offspring } \\
\text { to parents; }\end{array}$} & Mutimedia Instruction & & \\
\hline & & Lecture-Discussion & \multirow{6}{*}{$\begin{array}{l}\text { Acivity 1. Can you grow } \\
\text { new plants from "eyes?? }\end{array}$} & Laboratory Activity \\
\hline & & \begin{tabular}{|l|} 
Checklist \\
\end{tabular} & & Multmedia hstruction \\
\hline & & Graphic Oganizer & & \begin{tabular}{|l|} 
Laboratory Activity \\
\end{tabular} \\
\hline & & Research Revew & & Realias \\
\hline & & Reporing & & Lecture-Discussion \\
\hline & & Venn Dagram & & Collaborabive Leaming \\
\hline & & Checklist & \multirow{5}{*}{$\begin{array}{l}\text { Acivity 2. Can one } \\
\text { become two? }\end{array}$} & Mulimedia instruction \\
\hline & \multirow{6}{*}{$\begin{array}{l}\text { 8. describe the process of } \\
\text { ferilization; }\end{array}$} & Mutimedia Instruction & & Cooperative Leaming \\
\hline & & Lecture-Discussion & & Lecture-Discussion \\
\hline & & Cooperative Leaming & & Brainstoming \\
\hline & & Laboratory Acj vity & & Boardvork \\
\hline & & Direct Instruction & & \\
\hline \multirow{2}{*}{\multicolumn{5}{|c|}{ III. Ecosystems }} \\
\hline & & & & \\
\hline \multirow{26}{*}{$\begin{array}{l}\text { 1. Components of an } \\
\text { ecosystem } \\
\text { 2. Ecological } \\
\text { relatonships } \\
\text { 2.1 Symbiotic } \\
\text { relationships }\end{array}$} & \multirow{6}{*}{$\begin{array}{l}\text { 9. differentate biotic from } \\
\text { abiotic components of an } \\
\text { ecosystem; }\end{array}$} & $\begin{array}{l}\text { Ih-School Field Trip } \\
\text { ectere-Discussion }\end{array}$ & & \\
\hline & & \begin{tabular}{|l} 
Mutimedia Instruction \\
\end{tabular} & \multirow{7}{*}{$\begin{array}{l}\text { Acivity 1. What does it } \\
\text { mean to be alive? }\end{array}$} & Role Playing \\
\hline & & GaleryWalk & & \begin{tabular}{|l} 
Laboratory Acsivity \\
\end{tabular} \\
\hline & & Boardvotk & & n-School Field Thips \\
\hline & & Lecture-Demonstration & & Sory Making \\
\hline & & Word Wall & & Comic Srio \\
\hline & \multirow{7}{*}{$\begin{array}{l}\text { 10. describe the different } \\
\text { ecological relationships } \\
\text { found in an ecosystem; }\end{array}$} & Mutimedia Instruction & & \begin{tabular}{|l|} 
Lecture-Discussion \\
\end{tabular} \\
\hline & & 4 Pics 1 Word & & Collaborative Leaming \\
\hline & & \begin{tabular}{|l|} 
In-School Field Trio \\
\end{tabular} & \multirow{5}{*}{$\begin{array}{l}\text { Activity 2. House mates? } \\
\text { Eco mates! }\end{array}$} & Cooperative Leaming \\
\hline & & Lecture-Discussion & & Film Shoving \\
\hline & & Brainstorming & & \begin{tabular}{|l} 
In-School Field Trips \\
\end{tabular} \\
\hline & & Reporing & & Laboratory Activity \\
\hline & & Research Revew & & Collaborative Leaming \\
\hline & \multirow{7}{*}{$\begin{array}{l}\text { 11. predict the effect of } \\
\text { changes in one population } \\
\text { on other populations in the } \\
\text { ecosystem; and }\end{array}$} & Mutimedia Instruction & \multirow{5}{*}{ Acsivity 3. Which eats what? } & Brainstoming \\
\hline & & Ques and Questioning & & Concept Mapping \\
\hline & & Consequence Mapping & & Laboratory Activity \\
\hline & & Picture Anal ysis & & Cooperative Leaming \\
\hline & & $\begin{array}{l}\text { Focus Goup Discussion } \\
\text { Lecure-Discussion }\end{array}$ & & \begin{tabular}{|l} 
Boardvork \\
Piche Analysis
\end{tabular} \\
\hline & & \begin{tabular}{|l|} 
Picture Anal ysis \\
\end{tabular} & \multirow{6}{*}{ Activity 4. Lets Compare } & Uking lllustrations \\
\hline & & Simulation & & Adverisement Making \\
\hline & \multirow{6}{*}{$\begin{array}{l}\text { 12. predict the effect of } \\
\text { changes in abiotic factors on } \\
\text { the ecos ystem. }\end{array}$} & Mutimedia Instruction & & Cooperative Leaming \\
\hline & & Lecure-Discussion & & Music Ceation \\
\hline & & Ques and Questionning & & Project-Based Task \\
\hline & & P.O.E. & & Laboratory Acrivty \\
\hline & & Direct Instruction & & \\
\hline & & Repor & & \\
\hline
\end{tabular}

Table 6

GRADE 8

Summary of All Strategies Used In Terms of the Content and Skill

\begin{tabular}{|c|c|c|c|c|}
\hline Content & Learning Competencylies & Strategies & Acitivitylies & Strategies \\
\hline \multicolumn{5}{|c|}{ 1. Structures and Functions: Focus on the Digestive System } \\
\hline \multirow{39}{*}{$\begin{array}{l}1.1 \text { Crgans of the } \\
\text { digestive system and } \\
\text { heir interaction with } \\
\text { organs of the } \\
\text { respiratory, circulatory, } \\
\text { and excretory systems } \\
1.2 \text { Changes in food as } \\
\text { tundergoes physical } \\
\text { and chemical digestion } \\
1.3 \text { Diseases resulting } \\
\text { rom nutrent defciency } \\
\text { and ingestion of harmful } \\
\text { substances } \\
1.4 \text { Preventon, } \\
\text { detection, and treatment } \\
\text { of diseases of the } \\
\text { digestive system }\end{array}$} & \multirow{11}{*}{\begin{tabular}{|l} 
\\
$\begin{array}{l}\text { 1. explain ingestion, } \\
\text { absoption, assimilation, and } \\
\text { excretion; }\end{array}$
\end{tabular}} & & \multirow{3}{*}{$\begin{array}{l}\text { Activity 1. Pan 1 A. A Gutsy } \\
\text { game }\end{array}$} & Playing A Board Game \\
\hline & & & & 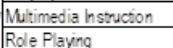 \\
\hline & & & & Gallery Wak \\
\hline & & & \multirow{4}{*}{$\begin{array}{l}\text { Activity 2. How do } \\
\text { enzymes affect digestion? }\end{array}$} & Laboratory Acivity \\
\hline & & & & Brainstorming \\
\hline & & 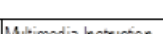 & & Cooperabive Leaming \\
\hline & & Lectre-Discussion & & $\begin{array}{l}\text { P.O.E. } \\
\text { Simulation }\end{array}$ \\
\hline & & \begin{tabular}{|l|l} 
Jigsawu \\
\end{tabular} & \multirow{6}{*}{$\begin{array}{l}\text { Activity } 3 \text {. How does pH } \\
\text { afect enzyme activity? }\end{array}$} & Laboratory Acjivity \\
\hline & & Role Playing & & Mutimedia hssuction \\
\hline & & Brainstorming & & Conseouence Maoping. \\
\hline & & Word Puzzle & & P.O.E. \\
\hline & & & & $\begin{array}{l}\text { Role Plavng } \\
\text { Cooperatue Leaming }\end{array}$ \\
\hline & \multirow{9}{*}{$\begin{array}{l}\text { 2. explain how diseases of } \\
\text { the digestive system are } \\
\text { prevented, detected, and } \\
\text { reated; }\end{array}$} & Mutimedia instruction & & Simulation \\
\hline & & Lecture-Discussion & \multirow{6}{*}{$\begin{array}{l}\text { Activity } 4 \text {. Ajoumey into } \\
\text { the digestive system }\end{array}$} & Mutimedia hstruction \\
\hline & & Research Revew & & Gallen Walk \\
\hline & & Role Playna & & Role Playno \\
\hline & & Cooperative Leaming & & Modelling \\
\hline & & Direct Instruction & & Direct Instruction \\
\hline & & \begin{tabular}{|l} 
Joumal Making \\
Modellino
\end{tabular} & & \begin{tabular}{|l|} 
Jigsaw \\
ahoratory Activity
\end{tabular} \\
\hline & & Projectbased task & \multirow{7}{*}{ Acsivity 1 . Am leaing, night? } & Tracking One's Meal \\
\hline & & Showand Tell & & Direct Instruction \\
\hline & & & & Thiva Questions \\
\hline & & & & Video Making \\
\hline & \multirow{10}{*}{$\begin{array}{l}\text { 3. idenofiy healthil pracices } \\
\text { that affect the digestive } \\
\text { system; }\end{array}$} & \begin{tabular}{|l} 
Dutimedia Instruction \\
Mutingeding
\end{tabular} & & Cooperafive Leaming \\
\hline & & Lecture-Discussion & & Modeling \\
\hline & & Role Playna & & Tracking One's Meal \\
\hline & & 4 Pics 1 Word & \multirow{8}{*}{$\begin{array}{l}\text { Activty } 2 \text {. What happens } \\
\text { vhen nurtional needs are } \\
\text { not adequately met? }\end{array}$} & Conseouence Maoping \\
\hline & & Boardvork & & Lecure-Discussion \\
\hline & & Branstormina & & Mutimedia instruction \\
\hline & & \begin{tabular}{|l} 
Joumal Making \\
\end{tabular} & & $\begin{array}{l}\text { Role Playng } \\
\text { Collaborative Leaming }\end{array}$ \\
\hline & & Research Revew & & Cooperative Leaming \\
\hline & & Showand Tell & & Ques and Questionning. \\
\hline & & Word Puzzle & & Joumal Making \\
\hline & & & & Reooring \\
\hline & & & \multirow{5}{*}{$\begin{array}{l}\text { Activity 3. Ubing essential } \\
\text { concepts in nurtiton to } \\
\text { planning a menu }\end{array}$} & Planning A Healhy Diet \\
\hline & & & & 3-Day Menu \\
\hline & & & & Joumal Making \\
\hline & & & & Cooperative Leaming \\
\hline & & & & Oues and Questionning \\
\hline
\end{tabular}

Table 7 
GRADE 8

Summary of All Strategie s Used In Terms of the Content and Skill

\begin{tabular}{|c|c|c|c|c|}
\hline Content & Leaming Competency/ies & Strategies & Acitivity/ies & Strategies \\
\hline \multirow{33}{*}{$\begin{array}{l}\text { 2.1 Stages of mitosis } \\
2.2 \text { Stages of meiosis } \\
2.3 \text { Mendelian Genetics }\end{array}$} & \multirow{2}{*}{\multicolumn{2}{|c|}{ and Variation of Traits }} & & \\
\hline & & & \multirow{4}{*}{$\begin{array}{l}\text { Acsivty } 1 \text {. Observing } \\
\text { mitosis }\end{array}$} & Mulimedia Instruction \\
\hline & & & & \begin{tabular}{|l} 
Loboratory Acsivity \\
\end{tabular} \\
\hline & & & & \begin{tabular}{|l} 
Goophic Organi zer \\
Story Moking \\
\end{tabular} \\
\hline & & & & Cooperative Leaming \\
\hline & & & \multirow{4}{*}{$\begin{array}{l}\text { Activty 2. Comparing } \\
\text { mitosis and meiosis }\end{array}$} & \begin{tabular}{|l} 
Venn Disgram \\
\end{tabular} \\
\hline & & & & Cooperafive Leaming \\
\hline & & & & Broinstorming \\
\hline & & & & \begin{tabular}{|l}
-2000 ortiory Acs Viy \\
Simulstion
\end{tabular} \\
\hline & & & \multirow{4}{*}{$\begin{array}{l}\text { Acsivey } 3 \text {. Tossing coins } \\
\text { and probability }\end{array}$} & Loboratory Acs Vity \\
\hline & \multirow{3}{*}{$\begin{array}{l}\text { 4. compare mitosis and } \\
\text { meiosis, and their role in the } \\
\text { cell-divsion cycle; }\end{array}$} & Lecture-Discussion & & $\begin{array}{l}\text { Multimedia Instructon } \\
\end{array}$ \\
\hline & & Mulimedia Instruction & & Consequence Mooping \\
\hline & & Show and Tell & & Cooperofive Leaming \\
\hline & & Broins torming & \multirow{6}{*}{$\begin{array}{l}\text { Activity } 4 \text {. Comparing } \\
\text { genotypic and phe notypio } \\
\text { ratios for a typical } \\
\text { Mendelian trat }\end{array}$} & \begin{tabular}{|l} 
Boardvok \\
Lecture-Discussion
\end{tabular} \\
\hline & & & & Broinstorming \\
\hline & \multirow{5}{*}{$\begin{array}{l}\text { 5. explain the significance of } \\
\text { meiosis in mointaining the } \\
\text { chromosome number; }\end{array}$} & Mutsmedia Instruction & & Reporting \\
\hline & & Ploture Anslyais & & Laboratry Activty \\
\hline & & Music Creation & & Modular-Bused instruction \\
\hline & & Concerot Moo & & Think-Pair-Share \\
\hline & & Lecture - Demonstration & \multirow{7}{*}{$\begin{array}{l}\text { Activty } 5 \text {. Filling up the } \\
\text { Punnet square for a } \\
\text { dinybrid cross }\end{array}$} & Boardvotk \\
\hline & & & & Collabortive Leoming \\
\hline & \multirow{6}{*}{$\begin{array}{l}\text { 6. predict phe notypic } \\
\text { expressions of trats } \\
\text { following simple patems of } \\
\text { inheritance; }\end{array}$} & & & Reciorocal Te aching \\
\hline & & Boand vork & & Brainstorming \\
\hline & & \begin{tabular}{|l} 
Mutmedis instrucion \\
Lectire-Discussion
\end{tabular} & & Boardvok \\
\hline & & P.O.E. & & Laborthory Ac5 Vty \\
\hline & & Reciorocal Te aching & & Simulasion \\
\hline & & Simulation & \multirow{4}{*}{$\begin{array}{l}\text { Activty } 6 \text {. Phe notypes and } \\
\text { genotypes in incomplete } \\
\text { dominanoe }\end{array}$} & Lecture-Discussion \\
\hline & & & & $\begin{array}{l}\text { Boardvotk } \\
\text { Cooperofive Leaming } \\
\text { P.O.E. }\end{array}$ \\
\hline & & & & Laboratory Act vity \\
\hline & & & & Mulfmedia Instruction \\
\hline & & & \multirow{3}{*}{$\begin{array}{l}\text { Activty } 7 \text {. Inferring } \\
\text { genotypes of ABO blood } \\
\text { types based on the } \\
\text { lorental blood tyoes }\end{array}$} & Boardvok \\
\hline & & & & Brainstorming \\
\hline & & & & \begin{tabular}{|l} 
P.O.E. \\
Reciono Te.
\end{tabular} \\
\hline \multirow{16}{*}{$\begin{array}{l}\text { 3.1 Species diversity } \\
\text { 3.2 Herarchical } \\
\text { taxonomic system of } \\
\text { las sifoution } \\
\text { 3.3 Protection and } \\
\text { conservation of } \\
\text { endang ered and } \\
\text { economically imporant } \\
\text { species }\end{array}$} & \multirow{7}{*}{$\begin{array}{l}\text { 7. explain the concept of a } \\
\text { species; }\end{array}$} & & & \\
\hline & & Lecture-Discussion & & \\
\hline & & Mitmedia Instruction & \multirow{4}{*}{$\begin{array}{l}\text { Activty } 1 \text {. Whats in a } \\
\text { name? }\end{array}$} & Name Gome \\
\hline & & Broinstorming & & \begin{tabular}{|l} 
Memory Gume \\
\end{tabular} \\
\hline & & Pole Playing & & Jigsaw \\
\hline & & $\begin{array}{l}\text { Drect instivction } \\
\text { Jigsow }\end{array}$ & & \begin{tabular}{|l} 
Word Wall \\
Word Puzzle
\end{tabular} \\
\hline & & Word Wall & & \\
\hline & \multirow{5}{*}{$\begin{array}{l}\text { 8. classify org anisms using } \\
\text { the hie orchical taxonomic } \\
\text { syste m; }\end{array}$} & Lecture-Discussion & \multirow{4}{*}{$\begin{array}{l}\text { Acsivity } 2 \text {. Howdo bacteria } \\
\text { in yogut look like? }\end{array}$} & Laboratory Act Vity \\
\hline & & Jigsow & & Mitimedia Instruction \\
\hline & & Memory Gume & & Model Moking \\
\hline & & Gollery Wolk & & P.O.E. \\
\hline & & Laboratory Acsvivy & & \\
\hline & \multirow{4}{*}{$\begin{array}{l}\text { 9. explain the ad vantage of } \\
\text { high biodiversity in } \\
\text { maintaining the stability of an } \\
\text { ecosystem; }\end{array}$} & Lecture-Discussion & \multirow{3}{*}{$\begin{array}{l}\text { Activity } 3 \text {. What can you do } \\
\text { to prevent dengue? }\end{array}$} & Debote \\
\hline & & P.O.E. & & Role Play \\
\hline & & Joumal Making & & Direct instruction \\
\hline & & Drect instruction & & \\
\hline
\end{tabular}

Table 8

GRADE 8

Summary of All Strategies Used In Terms of the Content and Skill

\begin{tabular}{|c|c|c|c|c|}
\hline Content & Leaming Competencylies & Strategies & Acitivity/ies & Strategies \\
\hline 4. Ecosystems & & & & \\
\hline \multirow{21}{*}{$\begin{array}{l}4.1 \text { Transfer of Energy in } \\
\text { Trophic Levels } \\
4.2 \text { Cycling of matenals } \\
\text { in the ecosystem } \\
4.2 .1 \text { Water cycle }\end{array}$} & \multirow{4}{*}{$\begin{array}{l}\text { 10. describe the transfer of } \\
\text { energy through the trophic } \\
\text { levels; }\end{array}$} & Using llustrations & & \\
\hline & & \begin{tabular}{|l|} 
Lecture-Discussion \\
\end{tabular} & \multirow{4}{*}{$\begin{array}{l}\text { Acjivity } 4 \text {. What is the } \\
\text { imporance of biodiversity } \\
\text { to ecosyste ms? }\end{array}$} & Multmedia hstruction \\
\hline & & Cooperative Leaming & & Cooperative Leaming \\
\hline & & Puzzle Works & & Brainstorming \\
\hline & \multirow{4}{*}{$\begin{array}{l}\text { 11. anal yze the roles of } \\
\text { organisms in the cycling of } \\
\text { matenals; }\end{array}$} & $\begin{array}{l}\text { Lecture -Demonstration } \\
\text { Remrom }\end{array}$ & & Reaction Papers \\
\hline & & Teporeng & \multirow{3}{*}{ Acivity 5. I create the future } & Role Playng \\
\hline & & Lecture-Discussion & & Simulation \\
\hline & & \begin{tabular}{|l} 
Mutimedalinstuction \\
Role Plaing
\end{tabular} & & Brainstorming \\
\hline & \multirow{4}{*}{$\begin{array}{l}\text { 12. explain howmaterials } \\
\text { cycle in an ecosystem; and }\end{array}$} & Picture Analysis & \multirow{4}{*}{$\begin{array}{l}\text { Activity 1. Howdo you } \\
\text { dentify the components of } \\
\text { a food chain in an } \\
\text { ecosystem? }\end{array}$} & Cassifyno Oroanisms \\
\hline & & Lecture-Discussion & & Picture Puzzle \\
\hline & & Mulfimedia In struction & & Reporing \\
\hline & & P.O.E. & & Music Creation \\
\hline & \multirow{9}{*}{$\begin{array}{l}\text { 13. suggest veys to } \\
\text { minimize human impact on } \\
\text { the environment. }\end{array}$} & Concept Maoping & \multirow{4}{*}{ Activity 2. Making food ve } & Making Illustrations \\
\hline & & Mulimedia Playng & & Boardvork \\
\hline & & Poem Making & & Concept Mapping \\
\hline & & Role Playing & & Cooperative Leaming \\
\hline & & Poster Presentation & \multirow{4}{*}{$\begin{array}{l}\text { Acjivity 3. Meat eaters vs. } \\
\text { plant eaters }\end{array}$} & Cooperative Leaming \\
\hline & & Consequence Mapping & & Venn Dagram \\
\hline & & Project based task & & Ficure Puzzle \\
\hline & & Lecture-Discussion & & Debate \\
\hline & & Music Creation & & \\
\hline
\end{tabular}

Table 9 
GRADE 9

Summary of All Strategies Used $\mathbf{n}$ Terms of the Content and Skill

\begin{tabular}{|c|c|c|c|c|}
\hline Cortent & Leaming Competency/ies & Strategies & Acitivitylies & Strategies \\
\hline \multirow{34}{*}{$\begin{array}{l}\text { 1. Respiratory and } \\
\text { Croulatory Systems } \\
\text { Working vith the other } \\
\text { Organ Systems }\end{array}$} & tions: Focus on the Digestive & System & & \\
\hline & & & \multirow{6}{*}{$\begin{array}{l}\text { Activity 1. What a Bunch of } \\
\text { Grapes! }\end{array}$} & \begin{tabular}{|l|l|l|} 
Moding \\
\end{tabular} \\
\hline & & & & \begin{tabular}{|l} 
Mutimedia instuction \\
Model ling
\end{tabular} \\
\hline & & & & \begin{tabular}{|l|} 
Cooperative Leaming \\
\end{tabular} \\
\hline & & & & Brainstorming \\
\hline & & & & $\begin{array}{l}\text { Collaborative Le aming } \\
\text { Laboratory Activty }\end{array}$ \\
\hline & & & & Lecture-Discussion \\
\hline & & & \multirow{4}{*}{ Activity 2. Botted Balloons } & $\begin{array}{l}\text { Cooperafive Leaming } \\
\text { Simulation } \\
\end{array}$ \\
\hline & & & & P.O.E. \\
\hline & & & & Collaboraive Le aming \\
\hline & & & & $\begin{array}{l}\text { Consequence Mapoping } \\
\text { Laboratory Activity }\end{array}$ \\
\hline & & & \multirow{3}{*}{$\begin{array}{l}\text { Acsivity 3. Just Go with the } \\
\text { Flovi }\end{array}$} & Simulation \\
\hline & & & & Cooperasive Leaming \\
\hline & & & & \begin{tabular}{|l} 
Mutimedia hstuction \\
Laboratory Acsivty \\
\end{tabular} \\
\hline & & & \multirow{4}{*}{ Activity 4. Lets Organize! } & $\begin{array}{l}\text { Concept Mapping } \\
\text { Pichure Puzzle } \\
\end{array}$ \\
\hline & & & & Cooperative Leaming \\
\hline & & & & $\begin{array}{l}\text { Peer Teaching } \\
\text { Laboratory Acsivity }\end{array}$ \\
\hline & \multirow{5}{*}{$\begin{array}{l}\text { 1. explain howthe respiratory } \\
\text { and circulatoysystems vokk } \\
\text { togeher to transport nutrents, } \\
\text { gases, and oner molecules to } \\
\text { and from the different parts of } \\
\text { the body. }\end{array}$} & Model Making & & Music Creation \\
\hline & & Mutmedia hstruction & \multirow{5}{*}{ Acsivity 5. Pump t! } & Simulation \\
\hline & & \begin{tabular}{|l|} 
Lecture-Discussion \\
\end{tabular} & & Cooperative Leaming \\
\hline & & Role Paving & & P.O.E. \\
\hline & & $\begin{array}{l}\text { Research Revew } \\
\text { Collaborative Leaming }\end{array}$ & & \begin{tabular}{|l} 
Reciorocal Teaching \\
Laboratory Actity
\end{tabular} \\
\hline & & & & Mutimedia Instruction \\
\hline & & & \multirow{4}{*}{$\begin{array}{l}\text { Acsiviy 6. The Rhychm of } \\
\text { my lean }\end{array}$} & Collaborab ve Leaming \\
\hline & \multirow{5}{*}{$\begin{array}{l}\text { 2. infer howone's lifestyle } \\
\text { can affect the functioning of } \\
\text { respiratory and circulatory } \\
\text { syste ms; }\end{array}$} & Ques and Questioning & & \begin{tabular}{|l} 
Music Creation \\
$R E P R$
\end{tabular} \\
\hline & & Research Revew & & Research Revew \\
\hline & & Role Paving & & Mutimedia astruction \\
\hline & & Brainstorming & \multirow{7}{*}{$\begin{array}{l}\text { Accivity 7. Cigarete } \\
\text { Smoking is Dangerous to } \\
\text { Your Health }\end{array}$} & Mutimedia instuction \\
\hline & & Lecture-Discussion & & Pichre Analysis \\
\hline & & & & 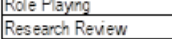 \\
\hline & & & & Laboratory Acjuty \\
\hline & & & & Lecture-Demonstration \\
\hline & & & & Lecture-Discussion \\
\hline & & & & Poster Mak \\
\hline
\end{tabular}

Table 10

GRADE 9

Summary of Al Strategies Used in Tems of the Content and Skill

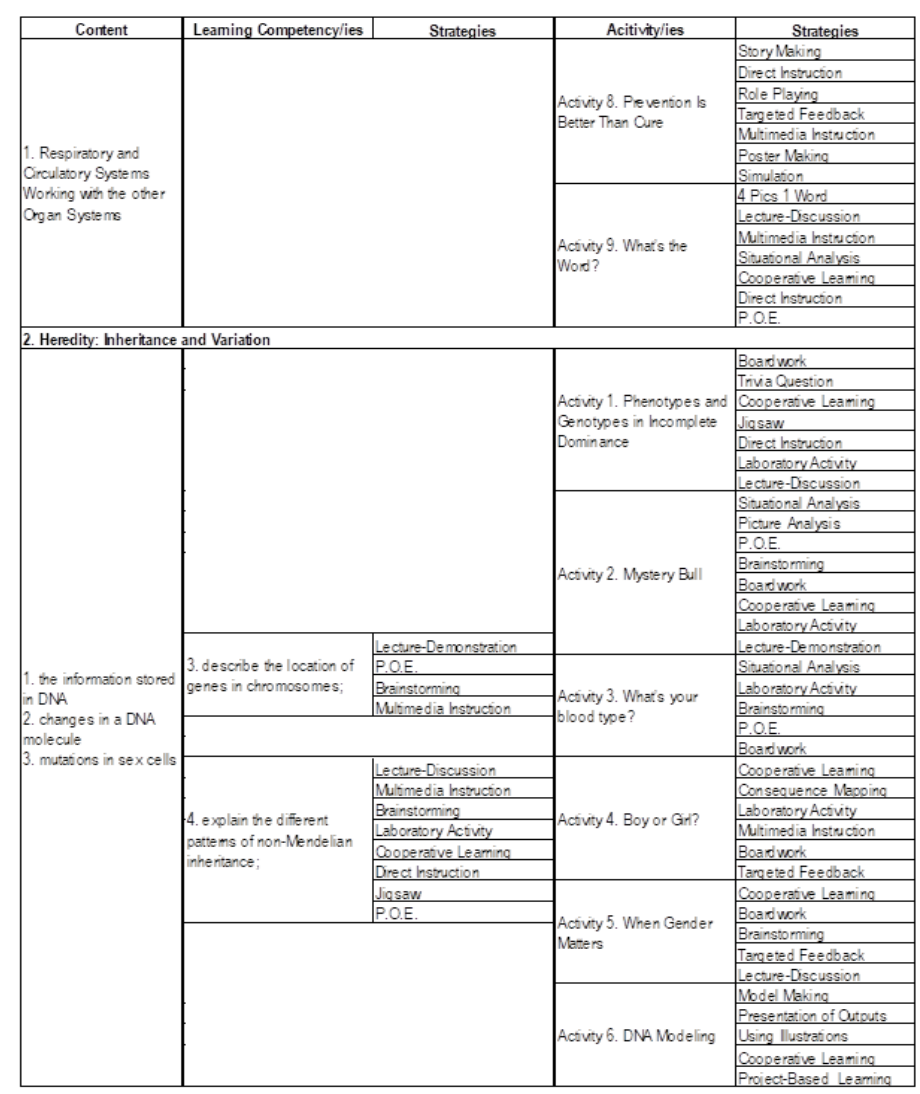

Table 11 
GRADE 9

Summary of Al Strategies Used in Terms of the Content and Skill

\begin{tabular}{|c|c|c|c|c|}
\hline Content & Leaming Competency/ies & Strategies & Acitivity/ies & Strategies \\
\hline \multicolumn{5}{|c|}{ 3. Biodiversity and Evolution } \\
\hline \multirow{25}{*}{$\begin{array}{l}\text { 1. howevolution through } \\
\text { natural selecion can } \\
\text { result in biodiversity }\end{array}$} & \multirow{17}{*}{$\begin{array}{l}\text { 5. relate species exinction } \\
\text { to the falure of populations } \\
\text { of org anisms to ad apt to } \\
\text { abrupt changes in the } \\
\text { environment; and }\end{array}$} & & \multirow{4}{*}{$\begin{array}{l}\text { Acjivity 1. Index of } \\
\text { Diversity }\end{array}$} & Cooperative Leaming \\
\hline & & & & In-School Field Trios \\
\hline & & & & Brainstorming \\
\hline & & & & \begin{tabular}{|l} 
Peer Teaching \\
P.O.E.
\end{tabular} \\
\hline & & & \multirow{7}{*}{$\begin{array}{l}\text { Activity 2. Measuring } \\
\text { Population Density }\end{array}$} & Cooperative Leaming \\
\hline & & & & In-School Field Trios \\
\hline & & & & Boardvork \\
\hline & & Mutmedia Instruction & & P.O.E. \\
\hline & & Brainstorming & & Collaborabive Leaming \\
\hline & & Cooperative Leamng & & Direct instruction \\
\hline & & In-School Field Trios & & Laboratory Activity \\
\hline & & 4 pics 1 vord & & Mutimedia Instuction \\
\hline & & Lecture-Discussion & & Cooperative Leaming \\
\hline & & P.O.E. & & Laboratory Acsivity \\
\hline & & Reporing & Activty 3. Endangered but & P.O.E. \\
\hline & & Triva Question & not Extinct. yet & Direct Instruction \\
\hline & & Word Puzzle & & Mutimedia Instuction \\
\hline & & & & Reporing \\
\hline & & & & Simulation \\
\hline & & & & Picture Analysis \\
\hline & & & & Brainstorming \\
\hline & & & Acsivity 5. Making & P.O.E. \\
\hline & & & Predictions & \begin{tabular}{|l|} 
Laboratory Activity \\
\end{tabular} \\
\hline & & & & Collaborative Leaming \\
\hline & & & & Lecture-Discussion \\
\hline
\end{tabular}

Table 12

GRADE 9

Summary of All Strategies Used in Terms of the Content and Skill

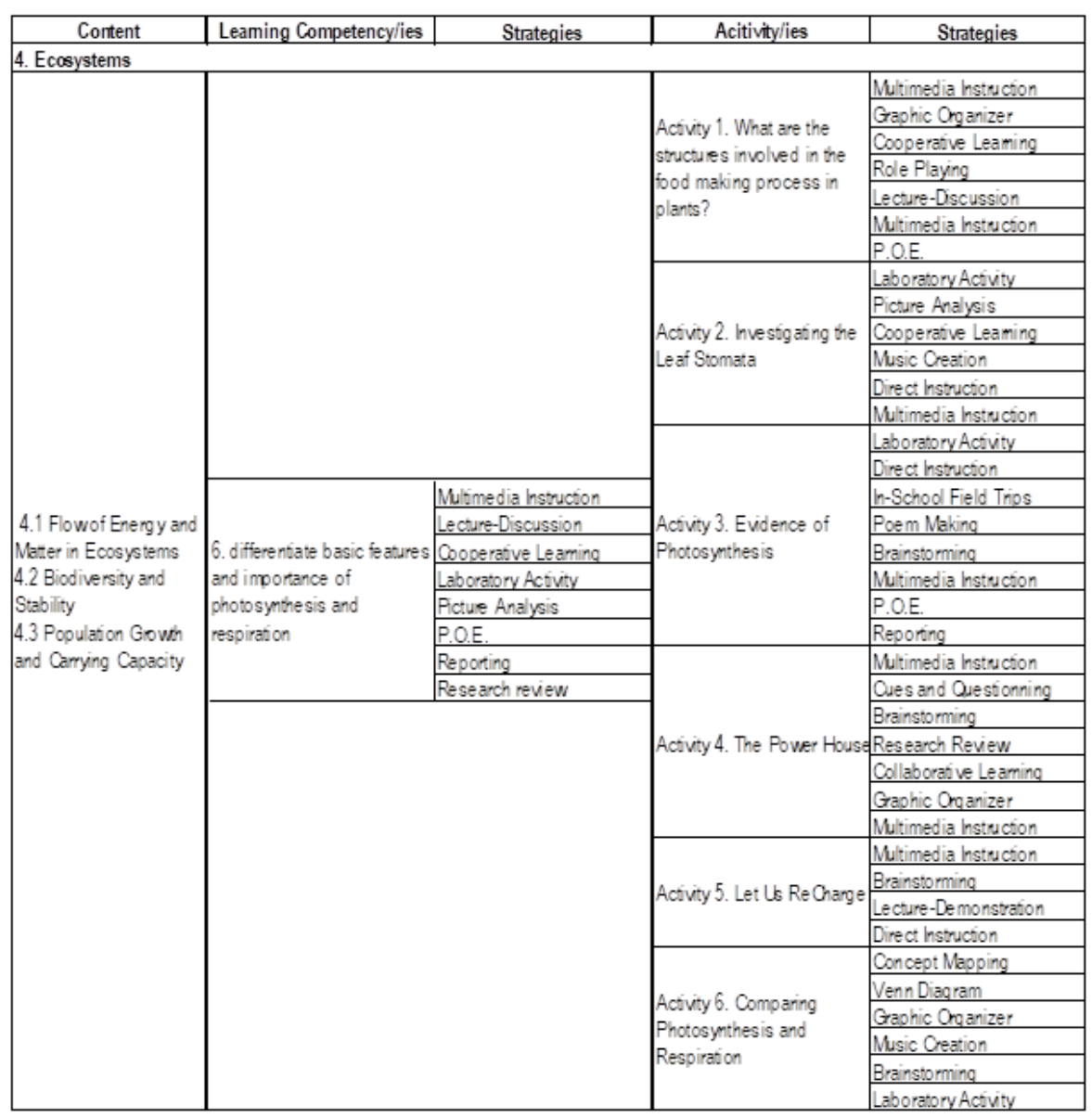

Table 13 
GRADE 10

Summary of All Strate gies Used Both in Content and Skills

\begin{tabular}{|c|c|c|c|c|}
\hline Content & Leaming Competency/ies & Strategies & Acitivity/ies & Strategies \\
\hline \multicolumn{5}{|c|}{ 1. Coordinated Functions of the Reproductive, Endocrine, and Nervous Systems } \\
\hline \multirow{37}{*}{$\begin{array}{l}1.2 \text { organisms as having } \\
\text { feedback mechanisms, } \\
\text { vhich ae coordinated } \\
\text { by the nervous and } \\
\text { endocrine systems } \\
\text { 1.3. how the se } \\
\text { feedback mechanisms } \\
\text { help the organism } \\
\text { maintain ho meostasis to } \\
\text { reproduce and survive }\end{array}$} & \multirow{10}{*}{\begin{tabular}{|l} 
\\
1. de scribe the parts of the \\
reproductive system and \\
heir tunctions;
\end{tabular}} & & \multirow{6}{*}{ Acjivty 1. Break it Doun! } & Concept Mapping \\
\hline & & & & Multimedia instruction \\
\hline & & & & Graphic Oganizer \\
\hline & & & & Reporting \\
\hline & & & & Boardvotis \\
\hline & & & & Laboratory Activity \\
\hline & & Multime dia instruction & \multirow{5}{*}{$\begin{array}{l}\text { Activity 2. How Fast is Your } \\
\text { Peaction? }\end{array}$} & Cooperasve Leaming \\
\hline & & Brainstorming & & Laboratory Activity \\
\hline & & Lecture-Discussion & & \begin{tabular}{|l} 
Multimedia instruction \\
\end{tabular} \\
\hline & & Repoting & & Simulation \\
\hline & & & & \begin{tabular}{|l|} 
Brainstorming \\
Peciprocal Teaching
\end{tabular} \\
\hline & \multirow{6}{*}{$\begin{array}{l}\text { 2. explain the role of } \\
\text { homones involved in the } \\
\text { female and male } \\
\text { reproductive systems; }\end{array}$} & Lecture-Discussion & \multirow{6}{*}{ Activity 3. A Nervous Trip } & Fole Playing \\
\hline & & Pick and Match & & Cooperabive Leaming \\
\hline & & Concept Mapping & & Simulation \\
\hline & & \begin{tabular}{|l|} 
Video Making \\
\end{tabular} & & Brainstorming \\
\hline & & Word Puzzle & & Laboratory Activity \\
\hline & & Concept Mapping & & Multimedia instruction \\
\hline & \multirow{6}{*}{$\begin{array}{l}\text { 3. de scribe the feedback } \\
\text { mech anisms involved in } \\
\text { regulating processes in the } \\
\text { female reproductive system } \\
\text { (e.g., menstrual cycle); }\end{array}$} & & \multirow{7}{*}{$\begin{array}{l}\text { Activity 4. Who's in } \\
\text { Control? }\end{array}$} & \begin{tabular}{|l} 
Mulfimedia instruction \\
Fole Playing
\end{tabular} \\
\hline & & Multomedia instruction & & Brainstorming \\
\hline & & Lecture-Discussion & & Laboratory Activity \\
\hline & & Brainstorming & & Concept Mapping \\
\hline & & Consequence Mapping & & Peer Teaching \\
\hline & & $\begin{array}{l}\text { Triva Que ston } \\
\text { Picture Analysis }\end{array}$ & & \begin{tabular}{|l|} 
Picture Analysis \\
Peciomol Teaching
\end{tabular} \\
\hline & \multirow{9}{*}{$\begin{array}{l}\text { 4. de scribe howthe nervous } \\
\text { system coord inates and } \\
\text { regulates the se feedback } \\
\text { mech anisms to maintain } \\
\text { homeostasis; }\end{array}$} & & & Showand Tell \\
\hline & & & \multirow{7}{*}{$\begin{array}{l}\text { Activity } 5 \text {. What Went } \\
\text { Wrong? }\end{array}$} & Lectue-Demonstration \\
\hline & & Multimedia instruction & & Picture Analysis \\
\hline & & Repoting & & Multimedia instruction \\
\hline & & Lecture-Discussion & & Laboratory Activity \\
\hline & & Triva Question & & Concept Mapping \\
\hline & & Focus Group Discussion & & Joumal Making \\
\hline & & Fole Playing & & Peer Teaching \\
\hline & & Brainstorming & \multirow{6}{*}{$\begin{array}{l}\text { Activity6. Mark My } \\
\text { Calendart }\end{array}$} & Laboratory Activity \\
\hline & & & & Picture Analysis \\
\hline & & & & $\begin{array}{l}\text { Cooperafive Leaming } \\
\text { Mutimedia nstuction }\end{array}$ \\
\hline & & & & Boardviok \\
\hline & & & & Concept Mapping \\
\hline & & & & Peer Teaching \\
\hline
\end{tabular}

Table 14

GRADE 10

Summary of All Strate gies Used Both in Content and Skills

\begin{tabular}{|c|c|c|c|c|}
\hline Content & Leaming Competency/ies & Strategies & Acitivity/ies & Strategies \\
\hline \multicolumn{5}{|c|}{ 2. Heredity: Inheritance and Variation } \\
\hline \multirow{39}{*}{$\begin{array}{l}\text { 1. the infomation stored } \\
\text { in DNA } \\
\text { 2. changes in a DNA } \\
\text { molecule } \\
\text { 3. mutations in sexcells }\end{array}$} & & \multirow{3}{*}{$\begin{array}{l}\text { Activty 1. Geting to Know } \\
\text { the DNA and RNA Structure }\end{array}$} & Graphic Organizer \\
\hline & & & & \begin{tabular}{|l} 
Cues and Que stoning \\
Laboratory Acfivity
\end{tabular} \\
\hline & & & & Cooperasve Leaming \\
\hline & & & \multirow{11}{*}{ Activity 2. DNA Makes DNA } & \begin{tabular}{|l} 
Model Making \\
\end{tabular} \\
\hline & & & & \begin{tabular}{|l|} 
Multimedia instruction \\
\end{tabular} \\
\hline & & & & $\begin{array}{l}\text { Cooperafive Leaning } \\
\end{array}$ \\
\hline & & & & \begin{tabular}{|l} 
Reseach Review \\
Brainstorming
\end{tabular} \\
\hline & & & & Boardvonk \\
\hline & & & & Concept Mapping \\
\hline & & & & Fole Playing \\
\hline & & & & Joumal Making \\
\hline & \multirow{6}{*}{$\begin{array}{l}\text { 5. explain howprotein is } \\
\text { made using information for } \\
\text { DNA; }\end{array}$} & Mlimedia hampction & & Laboratory Activity \\
\hline & & W & & Model Making \\
\hline & & Lecure-UIScussion & & Simulasion \\
\hline & & Wooperajue Learming & \multirow{5}{*}{$\begin{array}{l}\text { Activty } 3 \text {. What's the } \\
\text { Nessage }\end{array}$} & Cooperative Leaming \\
\hline & & Concept Mapping & & Boardvotik \\
\hline & & poard vork & & \begin{tabular}{|l} 
Laboratory Activity \\
\end{tabular} \\
\hline & & & & \begin{tabular}{|l} 
Branstorming \\
Concept Mapping
\end{tabular} \\
\hline & & & & R.E.P.R \\
\hline & \multirow{8}{*}{$\begin{array}{l}\text { 6. explain howmutat ons } \\
\text { may cause changes in the } \\
\text { structure and function of a } \\
\text { protein; }\end{array}$} & Multimedia Instruction & \multirow{9}{*}{$\begin{array}{l}\text { Activity 4. Relaythe } \\
\text { Nessage }\end{array}$} & Laboratory Activity \\
\hline & & Le cure-Discussion & & Word Wall \\
\hline & & Pick and March & & Peciprocal Teaching \\
\hline & & Research Revew & & Reporing \\
\hline & & Cooperabive Leaming & & Brainstorming \\
\hline & & Concept Mapping & & Concept Mapping \\
\hline & & brainstorming & & Cooperabive Leaming \\
\hline & & Triva Question & & Direct Instruction \\
\hline & & & & \begin{tabular}{|l|} 
Model Making \\
Multme dia Instruction
\end{tabular} \\
\hline & & & \multirow{5}{*}{ Activity5. Trace the Code } & Cooperabive Leaming \\
\hline & & & & \begin{tabular}{|l} 
Multomedia instruction \\
\end{tabular} \\
\hline & & & & Concept Mapping \\
\hline & & & & Laboratory Activity \\
\hline & & & & Peer Teaching \\
\hline & & & \multirow{6}{*}{ Activty6. Chromie Change } & Cooperafive Leaming \\
\hline & & & & htegras on of Content Areas \\
\hline & & & & 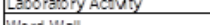 \\
\hline & & & & \begin{tabular}{|l|} 
Concent lanpina \\
\end{tabular} \\
\hline & & & & Lectue- Discussion \\
\hline & & & & Model Making \\
\hline
\end{tabular}

Table 15 
GRADE 10

Summary of All Strategies Used Both in Content and Skills

\begin{tabular}{|c|c|c|c|c|}
\hline Content & Learning Competency/ies & Strategies & Acitivity/ies & Strategies \\
\hline \multicolumn{5}{|c|}{ 3. Biodiversity and Evolution } \\
\hline \multicolumn{4}{|c|}{ Cassifying Organisms } & \\
\hline \multirow{40}{*}{$\begin{array}{l}\text { 1. howevolution through } \\
\text { natural selection can } \\
\text { result in biodivesity }\end{array}$} & & & & Picture Analysis \\
\hline & & & & Laboratory Acfivity \\
\hline & & & & $\begin{array}{l}\text { Cooperative Learning } \\
\text { Concept Maoping }\end{array}$ \\
\hline & & & & \begin{tabular}{|l|l} 
Direct Instruction \\
\end{tabular} \\
\hline & & & & Lecture-Discussion \\
\hline & & & \multirow{10}{*}{$\begin{array}{l}\text { Activity 2. AHA! } \\
\text { Analogous! Homologous! }\end{array}$} & Lecture-Demonstration \\
\hline & & & & Instructional Analysis \\
\hline & & & & \begin{tabular}{|l} 
Laboratory Activity \\
\end{tabular} \\
\hline & \multirow{10}{*}{$\begin{array}{l}\text { 7. explain ho wifossil } \\
\text { records, comparative } \\
\text { anato my, and genetic } \\
\text { information provide } \\
\text { evidence for evolution; }\end{array}$} & Lecture-Discussion & & Cooperabive Leaming \\
\hline & & Multimedia Instruction & & Brainstorming \\
\hline & & Cooperafive Leaming & & Concept Mapping \\
\hline & & Research Revew & & \begin{tabular}{|l} 
Laboratory Activity \\
\end{tabular} \\
\hline & & Brainstorming & & Cooperabive Leaming \\
\hline & & Concept Mapping & & Direct- Instruction \\
\hline & & Picture Analysis & & Picture Analysis \\
\hline & & Role Playing & \multirow{4}{*}{$\begin{array}{l}\text { Activity 3. So, who is My } \\
\text { Rel ative? }\end{array}$} & Brainstorming \\
\hline & & Simulation & & \begin{tabular}{|l|} 
Picture Analysis \\
\end{tabular} \\
\hline & & Word Puzzle & & Cooperafive Leaming \\
\hline & & & & Laboratory Acfivity \\
\hline & \multirow{10}{*}{$\begin{array}{l}\text { 8. explain the occurrence of } \\
\text { evolution; }\end{array}$} & & \multirow{6}{*}{ Activity 4. Lets Compare } & Graphic Organizer \\
\hline & & Film Shoving & & Laboratory Activity \\
\hline & & Multimedia Instruction & & Cooperabve Learning \\
\hline & & Lecture-Discussion & & Showand Tell \\
\hline & & Research Revew & & Concept Mapping \\
\hline & & 4 Pics 1 Word & & Reciprocal Teaching \\
\hline & & Brainstorming & \multirow{8}{*}{ Activty 5. Follow the Track } & Brainstorming \\
\hline & & Concept Mapping & & Cooperabive Leaming \\
\hline & & Cooperabive Leaming & & \begin{tabular}{|l|} 
Laboratory Activity \\
\end{tabular} \\
\hline & & Model Making & & \begin{tabular}{|l} 
Picture Analysis \\
\end{tabular} \\
\hline & & & & Concept Mapping \\
\hline & & & & Direct Instruction \\
\hline & & & & Showand Tell \\
\hline & & & & Story Making \\
\hline & & & \multirow{7}{*}{ Activity 6. Survivor } & Laboratory Activity \\
\hline & & & & Cooperative Leaming \\
\hline & & & & Multimedia Instruction \\
\hline & & & & Picture Analysis \\
\hline & & & & Brainstorming \\
\hline & & & & Concept Mapping \\
\hline & & & & Reporing \\
\hline
\end{tabular}

Table 16

GRADE 10

Summary of All Strate gies Used Both in Content and Skills

\begin{tabular}{|c|c|c|c|c|}
\hline Content & Leaming Competency/ies & Strategies & Acitivity/ies & Strategies \\
\hline \multicolumn{5}{|l|}{ 4. Ecosystems } \\
\hline \multirow{35}{*}{$\begin{array}{l}\text { 4.1 Fow of Energy and } \\
\text { Mater in Ecosystems } \\
4.2 \text { Biodiversity and } \\
\text { Stability } \\
4.3 \text { Population Grown } \\
\text { and Carrying Capacity }\end{array}$} & \multirow{13}{*}{$\begin{array}{l}\text { 9. explain how wpecies } \\
\text { diversity increases the } \\
\text { probability of ad aptation and } \\
\text { survivel of org anisms in } \\
\text { changing envronments; }\end{array}$} & & \multirow{6}{*}{$\begin{array}{l}\text { Activity } 1 \text {. Classifying the } \\
\text { Value of Biodiversity }\end{array}$} & Cooprafive Leaming \\
\hline & & & & Multome dia instruction \\
\hline & & & & n-School Field Trips \\
\hline & & & & Laboratory Activity \\
\hline & & & & Collaborative Leaming \\
\hline & & & & Concept Mapping \\
\hline & & & \multirow{5}{*}{$\begin{array}{l}\text { Activty 2. Dependent or } \\
\text { Independent? }\end{array}$} & Brainstorming \\
\hline & & Situational Analysis & & Peporing \\
\hline & & Brainstorming & & \begin{tabular}{|l|} 
Laboratory Acfivity \\
\end{tabular} \\
\hline & & Film Showing & & Concept Mapping \\
\hline & & K-W-H-L & & Situational Analysis \\
\hline & & Concept Mapping & \multirow{7}{*}{$\begin{array}{l}\text { Acfivity } 3 \text {. Analyzing } \\
\text { Envionmental Issues }\end{array}$} & Situational Analysis \\
\hline & & In-School Field Trips & & Fole Play \\
\hline & \multirow{6}{*}{$\begin{array}{l}\text { 10. explain the relafionship } \\
\text { betveen population groven } \\
\text { and carying capacity, and }\end{array}$} & & & Laboratory Activity \\
\hline & & & & Cooperafive Leaming \\
\hline & & Situational Analysis & & Concept Mapping \\
\hline & & Lecture-discussion & & Simulation \\
\hline & & Concept Mapping & & Targeted Feedback \\
\hline & & Cooperafve Leaming & \multirow{7}{*}{$\begin{array}{l}\text { Activity 4. Biodiversity } \\
\text { Status in the Community }\end{array}$} & Research Review \\
\hline & & & & Cooprative Leaming \\
\hline & & & & Targeted Feedback \\
\hline & \multirow{7}{*}{$\begin{array}{l}\text { 11. suggest vays to } \\
\text { minimize human impact on } \\
\text { the envionment. }\end{array}$} & Situational Analysis & & Laboratory Activity \\
\hline & & Brainstorming & & Brainstorming \\
\hline & & Lecture-Discussion & & Peporing \\
\hline & & Multimedia Instruction & & Survey Activity \\
\hline & & Cooperabve Leaming & \multirow{5}{*}{ Activity5. Product Creation } & Project-Based Task \\
\hline & & Re se arch Revew & & Cooperafive Leaming \\
\hline & & simulation & & Oulminating Activity \\
\hline & & & & \begin{tabular}{|l} 
Laboratory Activity \\
\end{tabular} \\
\hline & & & & Brainstorming \\
\hline & & & \multirow{5}{*}{$\begin{array}{l}\text { Activity6. Shovcasing of } \\
\text { Products }\end{array}$} & Project-Based Task \\
\hline & & & & Cooperative Leaming \\
\hline & & & & Brainstorming \\
\hline & & & & Laboratory Activity \\
\hline & & & & Dranstorming \\
\hline
\end{tabular}

Table 17 


\section{Conclusions}

There is a big gap between the common and not commonly used strategy both in content and skills in terms of its applicability and effectivity. This finding led to a revelation that teacher-respondents are still facing unceasing common problems such as unavailability of laboratory apparatuses and instructional materials which continuously hinders them at present to implement the strategies, they think are said to be effective. As a solution, they resorted to using what they call "traditional" way of teaching despite of knowing its ineffectiveness and impact on the students just for topic completion and convenience. Majority of them suggested adopting strategies that are hands-on and student-centered activities to fulfill the aim of the K to 12 curriculum which is learner-centered and inquiry-based. The matrix developed will be helpful to guide pre-service and in-service teachers in choosing appropriate strategies to be integrated into the instruction. The said matrix comprises the collection of teaching strategies that can be applied explicitly to every competency of the Biology curriculum across all grade levels. Therefore, the result of the study would be a wake-up call to pre-service teachers, in-service teachers, and administrators the need to practice various science teaching strategies as identified in the matrix to improve the performance of students both in Biology contents and skills.

\section{Recommendations}

Based on the findings and conclusion, the following are recommended: (a) the use of science innovative teaching strategies, technology-based materials and needs-based curriculum enabling teachers to build rapport between students and improve teaching and learning process (b) more trainings and seminars regarding the use of teaching strategies to immerse teachers into a variety of teaching strategies that can be used in teaching Biology (c) to conduct studies to thoroughly evaluate the effectiveness of the strategies as reflected in the matrix developed (d) constant monitoring to eradicate the unceasing problems of teachers which continuously affecting the teachers' vision of rendering effective instruction.

\section{References}

i. Adoniou, M. (2013). Preparing teachers - the importance of connecting contexts in teacher education.

ii. Australian Journal of Teacher Education, 38(8). Retrieved from http://dx.doi.org/10.14221/ajte.2013v38n8.7.

iii. Alsubaie, M. (2016). Curriculum development: Teacher involvement in curriculum development. Journal of

iv. Education and Practice, Vol.7, No.9. Retrieved from https://files.eric.ed.gov/fulltext/EJ1095725.pdf

v. Bada, S. (2015). Constructivism learning theory: A paradigm for teaching and learning. IOSR Journal of

vi. Research \& Method in Education, Volume 5, Issue 6 Ver. I. Retrieved from https://pdfs.semanticscholar.org/1c75/083a05630a663371136310a30060a2afe4b1.pdf

vii. Bordei, S. (2016). Theory of multiple intelligences - a winning strategy for tomorrow. Retrieved from

viii. https://www.researchgate.net/publication/309013784_Theory_of_Multiple_Intelligences_-

a_Winning_Strategy_for_Tomorrow

ix. Brame, C.J. and Biel, R. (2015). Setting up and facilitating group work: using cooperative learning groups

x. effectively. Retrieved from http://cft.vanderbilt.edu/guides-sub-pages/setting-up-and-facilitating-group-workusing-cooperative-learning-groups-effectively/

xi. Conrad, C. \& Bliemel, M. (2016). Psychophysiological measures of cognitive absorption and cognitive

xii. load in e-learning applications. Retrieved https://www.researchgate.net/publication/329075528_Psychophysiological_measures_of_cognitive_absorption_ and_cognitive_load_in_e-learning_applications

xiii. Garrett, T. (2008). Student-centered and teacher-centered classroom management: A case study of three

xiv. elementary teachers. Journal of Classroom Interaction, Vol 43.1, pages 34 - 47 . Retrieved from https://files.eric.ed.gov/fulltext/EJ829018.pdf

xv. Goffe, W. \& Kauper, D. (2014). A survey of principles instructors: Why lecture prevails. The

xvi. Journal of Economic Education. 45. 10.1080/00220485.2014.946547.

Retrieved from https://www.researchgate.net/publication/266742646_A_Survey_of_Principles_Instructors_Why_Lecture_Prevail $\mathrm{s}$

xvii. Gorontalo, N. (2018). The Development of Revised Jigsaw Collaborative Learning Model in Physics Subject at

xviii. Universitas. Global Journal of Educational Studies, Vol. 4, No. 2.

xix. Hastings, W. (2010). Expectations of a pre-service teacher: implications of encountering the unexpected. Asia-

xx. Pacific Journal of Teacher Education, 38(3), 207-219. Retrieved from https://doi.org/10.1080/1359866X.2010.493299

xxi. Johnson, D. \& Johnson, R. (2015). Cooperative learning: Improving university instruction by basing practice on validated theory. Journal on Excellence in College Teaching, 25. 85-118. Retrieved from https://www.researchgate.net/publication/284471328_Cooperative_Learning_Improving_university_instruction_ by_basing_practice_on_validated_theory

xxii. Kamamia, L. (2014). To establish the extent to which the subject mastery enhances quality teaching to studentteachers during teaching practice. International Journal of Education and Research, Vol. 2 No. 7. Retrieved from https://www.ijern.com/journal/July-2014/51.pdf

xxiii. Ketsman, 0. (2014). A mixed methods study of foreign language teachers implementing technology-enhanced multimedia instruction. World Journal on Educational Technology, 6 (2), 158-180. 
xxiv. Livingstone, K. (2014). Constructive alignment and the curriculum: A call for improved pedagogical practices in higher education. Journal of Business Management \& Social Sciences Research, Volume 3, No.12. Retrieved from https://www.researchgate.net/profile/Kerwin_Livingstone/publication/260766754_Constructive_alignment_and _the_curriculum_A_call_for_improved_pedagogical_practices_in_higher_education/links/55142d780cf23203199cf 303/Constructive-alignment-and-the-curriculum-A-call-for-improved-pedagogical-practices-in-highereducation.pdf

xxv. Lom, B. (2012). Classroom activities: Simple strategies to incorporate student-centered activities within undergraduate science lectures. Journal of undergraduate neuroscience education: JUNE : a publication of FUN, Faculty for Undergraduate Neuroscience. 11. A64-A71. Retrieved from https://www.researchgate.net/publication/236048997_Classroom_Activities_Simple_Strategies_to_Incorporate_S tudent-Centered_Activities_within_Undergraduate_Science_Lectures

xxvi. Magtolis, J. (2013). Students' conceptions on human organ systems: The case of university new entrants.

xxvii. IAMURE International Journal of Education. 6. 10.7718/iamure.ije.v6i1.498. Retrieved from https://www.researchgate.net/publication/312474885_Students'_Conceptions_on_Human_Organ_Systems_The_C ase_of_University_New_Entrants

xxviii. Mangila, B. (2018). Assessment of pre-service teachers on the practice teaching program: Inputs for program enhancement. Asia Pacific Journal of Education, Arts and Sciences, Vol. 5 No. 3 . Retrieved from http://apjeas.apjmr.com/wp-content/uploads/2018/11/APJEAS-2018.5.3.06.pdf

xxix. Mayer, R. (2014). Incorporating motivation into multimedia learning. Elsevier Learning and

xxx. Instruction, 29, 171-173. Retrieved from

https://pdfs.semanticscholar.org/3d2e/92f0bb4132ada0e7fe67d8cf389f9a0a9957.pdf

xxxi. Neary, M. \& Winn, J. (2009). The student as producer: reinventing the student experience in higher education.

Retrieved from

https://www.researchgate.net/publication/279681677_The_student_as_producer_Reinventing_the_student_expe rience_in_higher_education

xxxii. Pambid, R. (2015). Pre-service teachers methods of teaching strategies. Asia Pacific Journal of

xxxiii. Multidisciplinary Research, Vol. 3, No.1. Retrieved from http://www.apjmr.com/wpcontent/uploads/2015/02/APJMR-2015-3-182b-Pre-Service-Teachers-Methods-of-Teaching-

Science.pdf?fbclid=IwAR0uudMOeiyihC7HgT8U69dnKpS0bZOshtPJoFBbFncmfDUBWTkVD_O0DD0

xxxiv. Ralph, R.A. (2015). Post secondary project-based learning in science, technology, engineering and mathematics. Journal of Technology and Science Education (JOTSE), 6(1), 26-35. Retrieved from http://dx.doi.org/10.3926/jotse.155

xxxv. Schroeder et al. (2002). Effective K-12 science instruction elements of research-based science education.

xxxvi. Retrieved from http://cmse.tamu.edu/documents/LittlegreenBookletv3.pdf

xxxvii. Wurdinger, S. D., \& Carlson, J. A. (2010). Teaching for experiential learning: Five approaches that work.

xxxviii. Lanham, MD: Rowman \& Littlefield Education. 